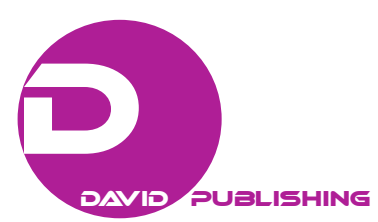

\title{
Factors That Influence Tax Avoidance in Indonesia Stock
}

\section{Exchange}

\author{
Yuniarwati, I Cenik Ardana, Sofia Prima Dewi, Caroline Lin \\ Tarumanagara University, Jakarta, Indonesia
}

\begin{abstract}
The purpose of this study was to obtain empirical evidence about the influence of the proportion of independent commissioners, audit committee, audit quality, profitability, and firm size against the tax avoidance. This study used a sample of one hundred and fifty three samples. These results indicate that profitability has an influence on tax avoidance while the proportion of independent commissioners, audit committee, audit quality, and firm size have no influence on tax avoidance.
\end{abstract}

Keywords: tax avoidance, the proportion of independent commissioners, audit committee, audit quality, profitability, firm size

\section{Introduction}

Tax is one of the driving forces of the Indonesian economy. It can be seen on the large tax revenues of Rp 1,546.7 trillion targeted by the government to finance the 2016 state budget from total state revenues of Rp 1,822.5 trillion (www.kemenkeu.go.id). This budget will be used to help build infrastructure and finance the administration. Receipts derived from taxes will be used by the government in providing public facilities and infrastructure that can not be provided by the private sector. Implementation of tax collection organized by the government does not always get a positive response from the community, especially the company. This is evident from the amount of tax ratio achieved by the state. The amount of tax ratio set at the beginning of 2016 amounted to 13.11 percent and decreased to 12.86 percent against Gross Domestic Product. Indonesia's tax ratio is still far behind other developing countries. Such a low tax ratio means that government revenue derived from tax revenues is still low (www.cnnindonesia.com). One of the factors that can affect the tax ratio is tax evasion activity performed by the taxpayer.

Many companies are racing to shrink tax payments. For a company, taxes as a cost can affect earnings and will affect the rate of return on investment. The company will endeavor to manage the amount of its tax payment to the lowest level because it will lower after-tax profit, rate of return, and cash flow. Conflict of interests between companies and governments is what causes the company tends to seek various ways to minimize the amount of tax payments both legally and illegally. The act of minimizing the amount of tax

Yuniarwati, SE, MM, Ak, CA, BKP, Faculty of Economics, Tarumanagara University, Jakarta, Indonesia.

I Cenik Ardana, Drs, MM, Ak, CA, Faculty of Economics, Tarumanagara University, Jakarta, Indonesia.

Sofia Prima Dewi, SE, M.Si, Ak, CA, Faculty of Economics, Tarumanagara University, Jakarta, Indonesia.

Caroline Lin, SE, Faculty of Economics, Tarumanagara University, Jakarta, Indonesia.

Correspondence concerning this article should be addressed to Yuniarwati, Faculty of Economics, Tarumanagara University, Jl. Tanjung Duren Utara No. 1, Jakarta Barat 11470, Indonesia. 
payments is illegally termed tax evasion while the action to minimize the amount of tax payments is legally referred to as tax avoidance.

\section{Tax Avoidance}

According to Suandy (2013) if a tax planning involves the activity in carrying out taxpayer engineering tax burden in order to minimize the tax burden by utilizing different regulations with the intent of the legislator, the tax planning activity referred to as tax avoidance. According to Suandy (2013) tax avoidance is:

A term used to describe the legal arrangements of tax payer's affairs so as to reduce his tax liability. It's often to pejorative overtones, for example it is use to describe avoidance achieved by artificial arrangements of personal or business affair to take advantage of loopholes, ambiguities, anomalies or other deficiencies of tax law. Legislation designed to counter avoidance has become more commonplace and often involves highly complex provision.

Based on these definitions, it can be concluded that tax avoidance is a way of reducing or avoiding the amount of tax burden in the manner permitted by taxation law by exploiting the opportunity of a deficiency in the tax law. The existence of deficiencies or loopholes can be exploited by the taxpayer to take the opportunity to make a good tax planning.

\section{The Proportion of Independent Commissioners}

To account for all business activities and complex company performance and to make it easier to ensure compliance with all laws and regulations in Indonesia, guidelines for implementation of work are made. Guidelines for implementation of work intended for board of commissioners, independent commissioners, and audit committee. Based on the implementation guidelines, the board of commissioners is formed with the aim to provide direction in the management of the company to the management and supervise in preparing financial statements that meet the applicable accounting standards so as to produce quality financial reports. To support the performance of the board of commissioners, then in the membership structure of the board of commissioners, each company must have an independent commissioner. Independent commissioners are meant to support the oversight function undertaken by the board of commissioners to better ensure that the management of the company is done well and produces objective financial reports. According to Winata (2014) companies have an independent commissioner in large numbers, and it will affect the independence of a company. This is because there is no direct relationship with shareholders. With the existence of independence, the tax avoidance policy can be lower. Based on the above description it can formulate a hypothesis as follows:

Ha1: The proportion of independent commissioners has an influence on tax avoidance.

\section{Audit Committee}

In addition to being required to have an independent commissioner, a company is also required to have an audit committee. The audit committee is established by the board of commissioners and is responsible to the board of commissioners. The audit committee is described as a monitoring mechanism to improve the independent oversight function of internal controls, corporate compliance, and reliable and relevant reporting of financial statements. Audit committees are useful in ensuring a clear transparency, fairness, and disclosure in the company's business activities. The audit committee within a company has an important role in ensuring that the company's financial statements are presented appropriately without any fraud according to the principles of good corporate governance. According to Winata (2014) the audit committee has a role in reducing the 
measurement and disclosure of improper accounting so as to assist in overcoming unlawful acts. Based on the above description it can formulate a hypothesis as follows:

Ha2: Audit committee has an influence on tax avoidance.

\section{Audit Quality}

In order to ensure that every business activity of the company is conducted with transparency, fairness, and clear disclosure, the company also requests assistance from audit service providers to better ensure business activities carried out by the management, especially in the presentation of financial statements and internal control of the company. To support the presentation of relevant and reliable financial statements and ensure reliable audits, firms tend to choose certain audit service providers. Financial reports audited by Big Four are believed to be more qualified than Non Big Four. Big Four is believed to show the true value of the company, so that fraud in the financial statements can be detected and produce a transparent report in accordance with the principles of good corporate governance. The purpose of the establishment of the structure of board of commissioners, independent commissioners, audit committees in a company and giving trust to the company providing audit services to perform a reliable audit process one of them is to indicate the existence of tax planning action in the form of tax avoidance activities which is intentionally done. The company hopes that by positioning the board of commissioners, independent commissioners, audit committees and entrusting audit service providers, the company can immediately detect and prevent tax avoidance. According to Annisa and Kurniasih (2012) the company's audited financial statements using audit services from the Big Four are believed to be more qualified. Companies audited by the Big Four have a lower fraud rate, so that information transparency can be measured through audit quality. Based on the above description it can formulate a hypothesis as follows:

Ha3: Audit quality has an influence on tax avoidance.

\section{Profitability}

Profitability is a measuring tool used in measuring the performance of a company by describing the company's ability to generate profits during a period. To sharpen profitability owned by the company, it used profitability ratio which is a reflection of the financial performance of a company. The higher the value of profitability owned by the company, the better the financial performance owned by the company. It can be assumed that if the company's profitability is high then the company does not take tax avoidance action. The amount of profits earned by the company will affect the amount of income tax a company. Increased earnings that affect the income tax, made a reason for the company to make tax avoidance. According to Kurniasih and Sari (2013) the value of the company's net profit will affect the amount of profitability. High profitability can provide an opportunity for companies to conduct a tax planning, which aims to reduce the amount of tax burden liabilities. Based on the above description it can formulate a hypothesis as follows:

Ha4: Profitability has an influence on tax avoidance.

\section{Firm Size}

Firm size can be used as a parameter to assign a company a large or small value. This parameter is used by the company by looking at the total value of the company's total assets, the stock market value, and the company's sales rate. The size of a large company can also mean the company has a good corporate value and demonstrate the ability of companies in carrying out economic activities. It can be assumed that if a company has a large firm size it has an indication that the company has good value so that the company does not make 
tax avoidance, but companies that have smaller size will be more potential to take tax avoidance. Companies categorized as large companies tend to have the ability to manage earnings compared to companies with a small total asset. According to Dewinta and Setiawan (2016) firms tend to avoid tax avoidance because companies earn a large and stable profit that affects the amount of tax burden borne by the company. According to Kurniasih and Sari (2013) companies with large size can always use the power they have to conduct a tax planning. The highlight and target of the regulator made an excuse to conduct a tax planning. Based on the above description it can formulate a hypothesis as follows:

Ha5: Firm size has an influence on tax avoidance.

\section{Materials and Methods}

The object of this study was the influence of the proportion of independent commissioners, audit committee, audit quality, profitability, and firm size against the tax avoidance on all manufacturing companies listed consistently in the Indonesia Stock Exchange during the years 2013-2015. The data used in this research are secondary data derived from the Indonesia Stock Exchange in the form of the issuer's financial statements during the years 2013-2015 manufacturing companies obtained from the website www.idx.co.id and data analysis of financial estimates published in finance.yahoo.com. This study uses a software program called Statistical Product and Service Solutions of Windows version 20 for data processing.

\section{Tax Avoidance}

Tax avoidance is a means undertaken in order to reduce or avoid the extent of the tax burden in the manner permitted by taxation law by exploiting the opportunity of a deficiency in tax law. According to Kurniasih and Sari (2013) tax avoidance can be measured by formula as follows:

Description:

$$
\text { CETR }=\frac{\text { Cash Tax Paid }}{\text { Pre-tax Income }}
$$

CETR = Cash Effective Tax Rate (cash issued for tax expense divided by profit before tax).

Cash Tax Paid = Amount of tax expense paid by company based on company's financial statements.

Pre-tax Income = Profit before corporate tax based on company's financial statements.

\section{The Proportion of Independent Commissioners}

Independent commissioners are members who are not allowed to establish relationships affiliated with shareholders, other commissioners, and directors. According to Cahyono, Andini, and Raharjo (2016) the proportion of independent commissioners is measured using the following ratios:

The Proportion of Independent Commissioners $=\frac{\text { Number of Indepedent Commissioners }}{\text { Total of Commissioners }}$

\section{Audit Committee}

The audit committee is responsible for assisting independent oversight of financial statements, risk management and overseeing corporate compliance with laws and regulations, improving the quality of financial statements and the effectiveness of internal and external. According to Damayanti and Susanto (2015) audit committee in this research is measured by using dummy variable which will give value one if having audit committee according to criteria, if not having audit committee and not according to criterion it will give value 0 . 
Audit committee criteria consist of at least one independent commissioner and at least two other members from outside the issuer.

\section{Audit Quality}

Auditing services on the Big Four or Non Big Four financial reports may affect the quality of the audit. Audit quality is the probability that the auditor will find and report a violation on the client's accounting system (Law, Elyzabeth, \& Setiawan, 2012). According to Damayanti and Susanto (2015) the quality of audit in this study is measured using dummy variables, which will give a value of one on the company's financial statements audited by the Big Four, if audited by the Non Big Four 0 .

\section{Profitability}

Return on Assets is an indicator that reflects the company's financial performance is shown by looking at the amount of capital capabilities of a company invested in assets to generate profits, the higher the value of Return on Assets that can be achieved by the company then the financial performance of the company can be categorized good. Return on Assets is measured using the following formula:

$$
\text { Return on Assets }=\frac{\text { Net Income }}{\text { Total Asset }}
$$

\section{Firm Size}

According to Kurniasih and Sari (2013) firm size is a classification based on total assets. Assets are depicted as a value that has a fairly stable level of stability (Darmawan \& Sukartha, 2014). The level of company growth can be seen from the total assets, the greater the total assets owned by the company can show good growth performance in the long term. According to Cahyono et al. (2016) company size can be calculated by the following formula:

$$
\text { Firm Size }=\text { Logaritma Natural Total Asset }
$$

\section{Results and Discussions}

The purpose of this analysis is to determine the effect of the proportion of independent commissioners, audit committee, audit quality, profitability, and firm size against the tax avoidance on manufacturing companies listed in Indonesia Stock Exchange during the years 2013-2015. The population in this study is all manufacturing companies listed in Indonesia Stock Exchange during the years 2013-2015. Based on these criteria a final sample of 153 data are obtained.

Table 1

T Test Results

\begin{tabular}{llllll}
\hline Model & $\mathrm{B}$ & Standard error & $t$ & Sig. & Conclusion \\
\hline Constant & 0.232 & 0.219 & 1.057 & 0.292 & Ha1 rejected \\
CIP & 0.045 & 0.024 & 1.893 & 0.060 & Ha2 rejected \\
AC & 0.008 & 0.033 & 0.254 & 0.800 & Ha3 rejected \\
AQ & 0.026 & 0.030 & 0.864 & 0.389 & Ha4 not rejected \\
PROF & -0.640 & 0.162 & -3.960 & 0.000 & Ha5 rejected \\
SIZE & 0.004 & 0.008 & 0.465 & 0.643 & .
\end{tabular}

Notes. The regression model obtained is: TA $=0.232+0.045$ CIP + 0.008 AC + 0.026 AQ - 0.640 PROF + 0.004 SIZE + e, where TA = Tax avoidance; CIP $=$ The proportion of independent commissioners; AC = Audit committee; $A Q=$ Audit quality; PROF = Profitability; SIZE = Firm size; and e = Error terms. Source: Output SPSS. 
The first alternative hypothesis (Ha1) in this study is that the proportion of independent commissioners has an influence on tax avoidance. Table 1 showed that the proportion of independent commissioners has the significant value of 0.060 where the value is more than 0.05 so that it can be concluded that the Ha1 is rejected or in other words the proportion of independent commissioners has no influence on tax avoidance. Independent commissioners are members who are not allowed to establish relationships affiliated with shareholders, other commissioners, and directors. The provisions stipulating the proportion of the board of commissioners shall consist of at least two members of the board of commissioners and one independent commissioner member, unable to provide an absolute guarantee that tax avoidance in a company can be avoided. According to Dewi and Jati (2014) the provision in granting the position of at least one independent person within a board of commissioners structure is possible only to meet the regulations applicable to a limited liability company. Parties that have an important role in a company are shareholders, so that all decisions are in the hands of shareholders so that the role of independent commissioners is not too dominant. The large number of independent commissioners can not control the management to act in accordance with self-interest, especially in minimizing taxes in the financial statements to increase corporate earnings. The results of this study are consistent with the results of research conducted by Dewi and Jati (2014), Kurniasih and Sari (2013), and Annisa and Kurniasih (2012). The results of this study are not consistent with the results of research conducted by Winata (2014) and Maharani and Suardana (2014).

The second alternative hypothesis (Ha2) in this study is that audit committee has an influence on tax avoidance. Table 1 showed that audit committee has the significant value of 0.800 where the value is more than 0.05 so that it can be concluded that the Ha2 is rejected or in other words audit committee has no influence on tax avoidance. According to the Decree of the Chairman of the Capital Market Supervisory Agency and LK, the audit committee shall consist of at least one member of an independent commissioner and shall consist of at least two other members from outside the issuer. The structure of an audit committee, chaired by an independent commissioner and a member of an independent commissioner or commissioner, can not provide an absolute guarantee that tax avoidance in a company can be avoided. The terms of the audit committee structure are only intended to meet the requirements of a limited liability company. According to Annisa and Kurniasih (2012), audit committee functions in improving the integrity and credibility of a financial report. If the audit committee within the company does not have the support of all elements of the company, then it is possible to avoid tax avoidance efforts. The results of this study are consistent with the results of research conducted by Damayanti and Susanto (2015) and Kurniasih and Sari (2013). The results of this study are not consistent with the results of research conducted by Dewi and Jati (2014) and Annisa and Kurniasih (2012).

The third alternative hypothesis (Ha3) in this study is that audit quality has an influence on tax avoidance. Table 1 showed that audit quality has the significant value of 0.389 where the value is more than 0.05 so that it can be concluded that the Ha3 is rejected or in other words audit quality has no influence on tax avoidance. According to Damayanti and Susanto (2015) companies that use the Big Four audit services tend to be trusted by the tax authorities, but if companies that use audit services can provide prosperity for reputable firms such as Big Four. Different opinions with Damayanti and Susanto (2015), Winata (2014) stated that there is no significant difference between firms audited by Big Four or Non Big Four against tax avoidance. This is because the auditing service of a financial report made by Big Four or Non Big Four has been based on existing auditing regulations, which is based on the Board of Professional Public Accountant Standards of the Indonesian Institute of Certified Public Accountants. The results of this study are consistent with the results of 
research conducted by Damayanti and Susanto (2015), Winata (2014), and Annisa and Kurniasih (2012). The results of this study are not consistent with the results of research conducted by Dewi and Jati (2014) and Maharani and Suardana (2014).

The fourth alternative hypothesis (Ha4) in this study is that profitability has an influence on tax avoidance. Table 1 showed that profitability has the significant value of 0.000 where the value is less than 0.05 so that it can be concluded that the Ha4 is not rejected or in other words profitability has an influence on tax avoidance. According to Damayanti and Susanto (2015) return on assets is an indicator used by the company in the framework of achieving corporate profits. Profit is one of the factors that can affect the consideration of tax payments. The net profit earned by the company is higher then it affects the level of company profitabilias, thus providing an opportunity for the company to position a tax planning that aims to reduce the amount of tax burden liabilities. The results of this study are consistent with the results of research conducted by Damayanti and Susanto (2015), Dewinta and Setiawan (2016), Maharani and Suardana (2014), Darmawan and Sukartha (2014), and Kurniasih and Sari (2013). The results of this study are not consistent with the results of research conducted by Cahyono et al. (2016).

The fifth alternative hypothesis (Ha5) in this study is that firm size has an influence on tax avoidance. Table 1 showed that firm size has the significant value of 0.643 where the value is more than 0.05 so that it can be concluded that the Ha5 is rejected or in other words firm size has no influence on tax avoidance. The size of the firm has no influence on increasing tax avoidance, which is because taxes are a corporate liability that must be met without exception. Large companies or small enterprises will always be a concern for the tax authorities in terms of fulfillment of tax obligations. This is because the tax is a state revenue that will be used in financing the expenditure of the state and in supporting economic and social activities intended for the community. Without state revenues derived from tax revenues, and relying on non-tax revenues, it would be difficult for the government to finance government activities and fulfill state responsibility for its citizens. The results of this study are consistent with the results of research conducted by Dewi and Jati (2014) and Annisa and Kurniasih (2012). The results of this study are not consistent with the results of research conducted by Dewinta and Setiawan (2016), Darmawan and Sukartha (2014), and Kurniasih and Sari (2013).

This study uses only independent variable in the form of the proportion of independent commissioners, audit committee, audit quality, profitability, and firm size. Further research should examine other factors which are expected to have an influence on tax avoidance but have not been tested in this study as age of company.

\section{References}

Annisa, N. A., \& Kurniasih, L. (2012). Pengaruh corporate governance terhadap tax avoidance. Jurnal Akuntansi dan Auditing, 8(2), 126-132.

Cahyono, D. D., Andini, R., \& Raharjo, K. (2016). Pengaruh Komite Audit, Kepemilikan Institusional, Dewan Komisaris, Ukuran Perusahaan, Leverage, Profitabilitas Terhadap Tindakan Penghindaran Pajak (Tax Avoidance) Pada Perusahaan Perbankan Yang Listing BEI Periode Tahun 2011-2013. Journal of Accounting, 2(2).

Damayanti, F., \& Tridahus, S. (2015). Pengaruh Komite Audit, Kualitas Audit, Kepemilikan Institusional, Risiko Perusahaan Dan retun on assets Terhadap tax avoidance. Jurnal Bisnis dan Manajemen, 5(2), 199-201.

Darmawan, I., \& Sukartha, M. (2014). Pengaruh Penerapan corporate governance, leverage, return on assets, Dan Ukuran Perusahaan Pada Penghindaran Pajak. E-Jurnal Akuntansi Universitas Udayana, 9(1), 143-150.

Dewi, N. N. K., \& Jati, I. K. (2014). Pengaruh Karakter Eksekutif, Karakteristik Perusahaan, Dan Dimensi Tata Kelola Perusahaan Yang Baik Pada Tax Avoidance Di Bursa Efek Indonesia. E-Jurnal Akuntansi Universitas Udayana, 6(2), 257. 
Dewinta, I. A. R., \& Setiawan, P. E. (2016). Pengaruh Ukuran Perusahaan, Umur Perusahaan, Profitabilitas, Leverage, dan Pertumbuhan Penjualan Terhadap Tax Avoidance. E-Jurnal Akuntansi Universitas Udayana, 14(3), 1593.

Kurniasih, T., \& Sari, M. M. R. (2013). Pengaruh Return On Assets, Leverage, Corporate Good Governance, Ukuran Perusahaan Dan Kompensasi Rugi Fiskal Pada Tax Avoidance. Buletin Studi Ekonomi, 18(1), 60-62.

Law, T., Elyzabeth, I. M., \& Setiawan, S. (2012). Pengaruh Kompetensi Dan Independensi Terhadap Kualitas Audit. Jurnal Akuntansi, 4(1), 35-34.

Maharani, I. G. A. C., \& Suardana, K. A. (2014). Pengaruh Corporate Governance, Profitabilitas Dan Karakteristik Eksekutif Pada Tax Avoidance Perusahaan Manufaktur. E-Jurnal Akuntansi Universitas Udayana, 9(2), 527.

Suandy, E. (2013). Perencanaan Pajak. Jakarta: Salemba Empat.

Winata, F. (2014). Pengaruh Corporate Governance Terhadap Tax Avoidance Pada Perusahaan Yang Terdaftar Di Bursa Efek Indonesia Tahun 2013. Tax \& Accounting Review, 4(1), 5-8. 